\title{
Europe fragmented over embryonic stem cell research
}

Embryonic stem cell (ES) research: California endorses it, and New Jersey, New York, and Massachusetts seem likely to follow suit, even though the next session of Congress may see it banned at a federal level. But problems establishing a consensus on regulation for this type of study are not limited to the United States. The European Union also has a major problem on its hands with ES research. New guidelines proposed by the European Commission last month, aimed at appeasing Catholic countries and stemming a scientific "brain drain," are set to be vehemently opposed by some member states.

"It's an absolute disaster," says Christine Mummery, a senior investigator at the Hubrecht Laboratorium in the Netherlands. Her country, along with Sweden, Finland, Greece, and Britain, permits the derivation of cell lines from embryos left over from in vitro fertilization research, so-called supernumerary embryos. However, at the present time, a moratorium on EC funding means that she is reliant on ready-made Australian/Singaporean cell lines, as she has no money to derive her own lines.

The one-year moratorium was introduced in September last year when the European Council of Science Ministers approved Europe's current four-year research program (Sixth Framework). The moratorium was instigated on the understanding that provisions for funding ES research would be established before the end of 2003. These were announced on July 9, and, if ratified, they will form the guidelines under which some forms of ES research will receive EU backing. The problem is that countries that have banned embryo research - notably Germany, Italy, Austria, and Ireland do not want their communal EU taxes supporting this work in other countries and are likely to oppose the guidelines.

\section{Proposed guidelines}

In a time-sensitive ruling mimicking that set by President Bush in August 2001, the EC guidelines state that only embryos frozen before June 27 , 2002 - the date of adoption of the Sixth Framework Programme - can be used for research. Yet this time stamp will make research in some countries virtually impossible. "In practical terms this excludes Denmark," says Professor Arne Sunde, chairman of the European Society of Human Reproduction and Embryology (ESHRE). Sunde has been one of the most vocal opponents of a European ban on ES research both because ESHRE contains a cadre of stem cell scientists and because regulation affecting embryo research also has an impact on assisted reproductive technology (ART) research. Denmark, he explains, has a two-year limit on cryopreserved embryos, after which date they are destroyed. Thus, by 2004 there will be no embryos left that predate the guideline cut-off point of June 2002, and Danish scientists will have to rely solely on imported cell lines.

In addition, says Sunde, "If you look at the proposals, you see that there are a lot of obstacles that the politicians can introduce. For example, research can only be funded when there is no adequate alternative available. Who will determine this? In particular, they must demonstrate that one cannot use existing adult stem cell lines. That's also impossible to prove scientifically at the moment." Just as troublesome is the general proviso that "research will be funded only when it is demonstrated that it meets particularly important research objectives." The way this will be decided and by whom is unclear.

"The guidelines will go to the European Parliament for a second reading, probably in the Fall," says Sunde. "It's extremely difficult to get an overview of what's happening because of the numerous bodies involved - the European Parliament, European Council, [European] Commission, and the subcommittees. It's hard to get a grasp of what's going on and where the real decisions will be made." The regulatory waters were already muddied by different groups earlier this year. In April, the European Parliament introduced a raft of amendments banning several aspects of ES research that are legal in Britain, such as the creation of embryos by somatic cell nuclear transfer (SCNT). Britain is currently the only European country that allows the practice. In June, the Employment, Social Policy, and Health Council decided against a ban on SCNT, leaving individual countries to exercise their own measures. But if resistant countries push hard enough, EU-wide law could still be introduced, overruling individual country regulations.

\section{"It's an absolute disaster." \\ -C. Mummery}

Sunde says that his own country, Norway, belongs to the conservative camp. "We have a conservative Christian government, and the Prime Minister is a former priest. Research on embryos has been banned since 1987. There are no prospects of getting this ban lifted." 


\section{Brain drain}

Speaking at a press conference to release the guidelines, EU Research Commissioner Philippe Busquin admitted that one incentive for their introduction is to prevent an exodus of stem cell scientists to the United Kingdom, Australia, and Singapore, where such research is legal, and also to the US, where work can be done with private funds. This 'brain drain' is epitomized by Roger Pedersen, who has moved from the University of California, San Francisco, to Cambridge, United Kingdom.

"There are certainly groups within Europe - Germany and France - asking whether people can come to our lab and work because they don't want to get behind with expertise," says Mummery. "They're convinced at some point that the ethical objections in their country will be reduced, and they're afraid they'll be behind. So people are planning to send post-docs within this new EU possibility to other countries."

Sunde believes such a strategy is immoral. "A 10-year perspective on this is when the Koreans, Australians, Britons and Swedes have succeeded in developing a treatment, perhaps for brain tumors, based on research that has been heavily dependent on ES cell research; do you think that the Germans will stop that coming into their country?" His point is reinforced by Germany's ES research policy; it allows the import of ES lines created in other countries prior to January 2002.

The same thing happened in the ART field, recalls Sunde, where advances relied on embryonic research. "A typical example is ICSI [intracytoplasmic sperm injection]. As soon as the data showed the safety of this, Germany and other countries imported it. In my country, before doing ICSI, we have to demonstrate in writing that we have the experience to do it, so I had to go to Belgium to be trained before coming back to Norway. For a country to have a position to let the others do the 'dirty work' and afterwards you benefit, that's immoral."
The current mismatch of policies also hinders collaboration. Wolfgang Franz of the University of Munich is one of only three German scientists approved to work with stem cell lines, which, according to German law, must be imported and have existed prior to January 2002. "We want to work with him," says Mummery, "but will he be allowed to work with us as we'll be deriving new lines?"

\section{Public funding, public knowledge}

Scientists are eager to gain public funding for their work largely because current efforts are supported by private biotechnology company funds. "The problem with most of the research being in biotech companies is that people haven't always been extremely honest about the problems they come across," says Mummery. "So we think it's a good thing that finance will be public so that you can do real scientific research without having an extra motive to convince everybody how wonderful

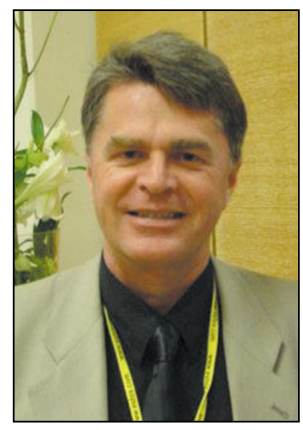

Arne Sunde Pushing for change in the EU. that new lines are needed. She says that, in practice, of the 70 or so lines registered with the US National Institutes of Health - the so-called "list of Bush" - only 6 to 11 are actually being distributed. And of the Australian lines, three were derived from one set of gamete donors, i.e., one cohort of embryos. "So there's not a great deal of genetic diversity among the lines, and it's rather difficult to base all conclusions on such a limited number - new lines are needed." She continues, "Furthermore, culture conditions have improved dramatically since the early lines were derived, so we need new lines not simply transferred when they're already at high passage to better culture conditions, but grown from scratch under better conditions. Also, if we ever use them for clinical applications, they will have to be derived under approved conditions of good manufacturing practice. So another set of lines will be necessary for clinical application." your research is."

Mummery's group has recently published on the differentiation of ES cells into cardiac myocytes in Circulation. "We've characterized this differentiation well, but we can't get enough of the cells to differentiate, and if I was working purely for a company, I wouldn't be able to say that. I'd have to be more vague. Fortunately, that aspect of my research is funded by the Dutch Academy of Science. They have given me startup funds to do this type of research, but for the derivation of new lines we'd probably rely on biotech funds [if funds are not forthcoming from the EU]."

\section{The need for new lines}

During the moratorium, Sixth Framework money can only be used for work on existing cell cultures, but Mummery outlines the reasons
While they wait to see whether the European Parliament approves or prohibits ES research funding, Mummery and others are looking to a new initiative. The Strasbourgbased European Science Foundation is developing an initiative called EUROCORES, which will send out calls for basic research proposals in October. If a project is approved by the the EUROCORES scientific evaluation group, investigators whose countries have agreed go back to their home countries and ask for the supporting funds. This could offer an escape route for those opposed to ES research but could also add another layer of confusion to an existing patchwork of regulation and funding for this field in Europe. to participate in the initiative can

Karen Birmingham, London 